\title{
ENVIRONMENTAL IMPACT ASSESSMENT IN ALBERTA
}

\author{
. P.S. ELDER*
}

\begin{abstract}
Environmental impact assessment, as practiced in Alberta, includes considerable social impact assessment requirements. The author, while favouring a comprehensive assessment and project approval process, argues that the Minister of the Environment lacks the legal authority to require project proponents to carry out socio-economic impact assessments. According to the author, the Energy Resources Conservation Board's power to require and consider social impact assessment in the approval process is also doubtful. Legislative clarification is desirable.
\end{abstract}

\section{INTRODUCTION}

Environmental impact assessment (EIA) is now well established in Canada; so is public participation. It is now unimaginable that we would abolish their formal place in the approval process for large scale projects. Too much unpredicted damage has been caused by developments which ignored social and environmental risks for us to return to tunnel vision project approval.'

Although their general principle is accepted, EIA and public participation are under fire from all sides. Some critics point out that the approval process is not holistic enough, that overall value choices are of ten not debatable in the approval process. They call for public involvement in "normative planning", the explicit selection of overall value choices from which "strategic" and "operational" plans are derived. ${ }^{2}$ They also criticize the disparity of resources and information between volunteer public interest intervenors and professional proponents. Others stress the need to streamline the process because of the expense and delay and consequent uncertainty involved in preparing exhaustive EIA's for projects which everybody knows will be built anyway. Public interest groups also find the length of the process to be exhausting and frustrating.

It is the intent of this article to describe the legal and policy approach taken to EIA's in Alberta. A generic description of Alberta's approval process for energy resource development will also be of fered. After some specification of terminology and a brief discussion of the role that EIA's can be reasonably expected to play, the environmental assessment mandates of various agencies, mainly the Department of the Environment and the Energy Resources Conservation Board (ERCB), will be examined. Although the author supports strengthening the EIA process and making it more holistic, he will nevertheless maintain that both the

- Professor of Law in Environmental Design, University of Calgary. I would like to thank the following people for their constructive comments on the draft article: Nigel Bankes (Faculty of Law, University of Calgary); Linda Duncan (Environmental Law Centre of Alberta); Constance D. Hunt (Canadian Institute of Resources Law (CIRL)); Janet Keeping (CIRL); Alastair R. Lucas (Faculty of Law, University of Calgary); W.A. Ross and D.A.R. Thompson (both of the Faculty of Environmental Design, University of Calgary).

1. Well known examples include the loss of the rich annual deposit of silt on the banks of the Nile after the Aswan Dam was built and consequent harm to farmers; the loss of nutrients for a sardine fishery at the mouth of the Nile due to the same project; the serious harm to native trapping due to the lowering of water levels in the Athabasca Delta in Alberta due to the building of the Bennett Dam in B.C.; etc.

2. The terms are derived from Ozbekhan. See L. G. Smith, "Mechanisms for Public Participation at a Normative Planning Level in Canada", Canadian Public Policy (1982) 7:4 Canadian Public Policy 56. 
Minister of the Environment and the ERCB may have exceeded their legal mandates in this area. This article will suggest that holistic project review is important and that the broad view of environmental assessment should be reflected more clearly in the appropriate legal mandates. Legislative amendments and changes in administration and staffing of approval agencies will be required to do this.

It should be noted that there is no attempt to cover all aspects of approvals of major projects. Thus, the possible roles of public health, social service and fish and wildlife of ficials have not been assessed.

Although there is not the space to argue all these points the author believes:

1. That the information generated by EIA procedures should play as important a role in obtaining governmental approvals as economic and technical information;

2. That the EIA process is not the appropriate vehicle for debate about overall government policy, although formal opportunity for such a debate should exist in the policy process and should precede the consideration of specific project proposals;

3. That nevertheless the mandate of both Alberta Environment and the ERCB should be broadened to include explicit consideration of socio-economic impacts and to make it clear that the Board can recommend alternatives to conventional energy development to the provincial Cabinet;

4. That a formal public participation mechanism should exist for reviewing EIA's for other than energy projects;

5. That the EIA and project approval process can be substantially improved without imposing undue expense or delay on project proponents. Some of these improvements will involve the increasing trend toward direct negotiations between proponents and local groups affected by the project, with the resulting agreements being incorporated into regulatory approval conditions.

\section{ENVIRONMENTAL IMPACT ASSESSMENT (EIA)}

The EIA involves "a study of the probable changes in the various socioeconomic and biophysical characteristics of the environment which may result from a proposed . . . action".$^{3}$ It should be done at a stage where serious environmental damage may be avoided or minimized. Indeed, the process should integrate "environmental with economic and social understanding at the very beginning of the design process". ${ }^{4}$ Although it is difficult or even impossible $e^{5}$ to predict accurately the responses of ecological systems even to known technologies, a complete EIA should attempt to do the following: ${ }^{6}$

1. describe and analyse the proposal;

3. R.K. Jain et al, Environmental Impact Analysis (1977) 3.

4. C.S. Holling (ed.), Adaptive Environmental Assessment and Management (1980) 3-4.

5. W.E. Rees, "Environmental Assessment and the Planning Process in Canada", Environmental Assessment in Australia and Canada (S. Clark ed. 1982) 33.

6. R. Lang, "Environmental impact assessment: reform or rhetoric?" Ecology versus Politics in Canada (W. Leiss ed. 1979) 234-235. 
2. inventory the natural and human environments and interests af fected by them;

3 predict the environmental effects, including direct, indirect and cumulative ef fects both on the site and on the region, giving irreversible effects and commitments and identifying who gains and loses;

4. evaluate both the magnitude and importance of those effects;

5. describe and evaluate possible mitigative measures;

6. describe alternatives both to the project (including the do-nothing alternative) and to the proposed means of carrying it out;

7. present the results of the analysis in an integrated format that helps decision makers.

To this list, the author would add:

8. provide for ongoing monitoring of impacts and of the success of mitigative measures;

9. specify procedures for abandonment of the project at the end of its economic life.

Thus, EIA involves a consideration of impacts in four phases of a project - design, construction, operation and abandonment - and emphasizes ongoing mitigation and monitoring. ${ }^{7}$

In a way, this is just a more comprehensive and systematic way of doing the common sense evaluation which people do for any decision. ${ }^{8}$ It is believed, however, that in the past environmental values have been underweighted and that planners and decision makers will be more likely to weigh them appropriately if they have adequate information. ${ }^{9}$ Obtaining the necessary baseline data over a representative period of time and carying out this comprehensive analysis may require considerable time and money, however. The encyclopaedic EIA may neither be attainable nor necessary for a reasonable decision.

Sometimes scientific uncertainty will force decision makers to weigh the level of risk in approving a project. In order to ensure that crucial data are provided without imposing information overload on decision makers or proponents, "scoping" and "tiering" techniques have been developed. The former involves determining which issues need detailed study, and the appropriate methodologies. The latter attempts to classify issues in an hierarchy from fundamental to localized.

Several difficult dilemmas remain. Single project assessment tends to be too narrow in focus. It is of ten carried out in a policy vacuum with limited information about regional or overall policy costs. ${ }^{10}$

Impact assessment, on a project-by-project basis requires a broader, coherent decision-

framework (including elements of national, provincial or regional development policy)

if it is to work as intended.

This implies not only coherent provincial policies but a co-ordination of the project's assessment by the various interested departments. Further, it shows the need for regional socio-economic effects to be considered by the assessment process.

7. L. McKay, Environmental Information in the Energy Resource Industry Calgary: Faculty of Environmental Design, University of Calgary (unpublished master's thesis) 1983, pp. 1214.

8. Supran. 6 at 242.

9. Id.

10. Supran. 5 at 24 . 
The narrow focus may also result in cumulative or longer term effects being ignored. Further, there is a danger that EIA may be shaped to meet the needs of the approval process rather than being used from the earliest planning phases to shape the project. The lack of baseline data may exacerbate this tendency.

It seems clear that the focus of the EIA in Canada has been to help identify and then mitigate environmental impacts, rather than exercising a veto over a project. ${ }^{11}$ There are examples, however, where environmental and social factors have resulted in projects being relocated. ${ }^{12}$ Even severe critics of EIA as practiced in Canada must concede that considerable progress in environmental management has occurred in large scale development projects. The difficult question is whether or to what extent the EIA process should accommodate deeper challenges to the idea that large scale development is the way to solve our problems.

Let us take an example of the type of issue involved. Some intervenors in the 1979 application by Esso Resources to build a large scale heavy oil extraction plant at Cold Lake wanted to argue that the plant was not necessary. They reasoned that Canadians were using energy so inefficiently that more was being wasted than the plant could produce. Furthermore, they claimed that it would be cheaper to undertake conservation measures to save that amount of energy. The cheaper solution even offered to generate more employment.

Suppose these claims were correct. In principle, they constituted a significant criticism of Alberta's (and Canada's) energy policy. If we did not need, or could not afford, simultaneous tar sands development and rigorous conservation programs, a debate on their comparative merits was both timely and important. Yet the ERCB refused to consider such issues in their report, and the Provincial Government ignored the issue in its response.

This example is not intended to criticize the ERCB, but to point out a gap in the approval process. One can understand a board's or a government's reluctance to reject a project on the grounds that another sector of the economy, possibly outside its jurisdiction, could be doing something more effectively to solve the perceived problem. The consequent problems of co-ordination or resource allocation would be considerable. Yet surely fundamental challenges to conventional policy, especially in a time of rapid change, must be accommodated somewhere. But perhaps it should not be in the project-specific EIA process.

There are different ways of slicing up the cake. We could have broad hearings by advisory bodies such as the Environment Council of Alberta on various policy sectors. We could leave "normative planning" in the energy field to the present needs requirements hearings of the ERCB. We

11. Alberta Environmental Assessment Steering Committee, Review of Alberta's Environmental Impact Assessment System Report and Recommendations Edmonton (June, 1980); A.R. Lucas "The Canadian Experience," supran. 5 at 146.

12. Two federal Environment Assessment Review Panels recommended against locating uranium yellow cake processing facilities in Port Granby, Ontario (1978) and Warman, Saskatchewan (1980). As well, the Ontario waste management corporation under well known environmenta!ist Donald Chant rejected a site for hazardous waste treatment plant even after the government of Ontario had announced the location. 
could develop generic technology assessment procedures or generic environmental impact assessments. What is needed, however, is a clear legal mandate for the task and the appointment of personnel who are open to new alternatives.

In the light of past experience, the author has concluded that a projectspecific EIA or approval process is not the best locus for the development of fundamental policy or for challenges to it. Clear overall provincial policies should be laid out after a full opportunity for public input, but the approval or hearing body considering specific projects should not be obliged each time to hear the latest theory about soft energy or the conserver society. At the same time, approval agencies should have the discretion to hear such new material and to recommend that such factors be considered by cabinet either generally or in the particular case. It is important that full access to the policy making and approval processes, together with open information and appropriate financial help, be provided to public interest intervenors. If these features are characteristic of a clearly defined process, both public alienation and legal challenges such as Bushell v. Secretary of State for the Environment ${ }^{13}$ can be avoided.

This English case, "possibly the most important case arising from a formal administrative adjudication since the Second World War," 14 involved a local inquiry considering objections about the proposed scheme of the Department of Environment to construct two 15 mile sections of road. Under the legislation, the policy of building a nationwide system of motorways was not to be questioned by local hearings. They were designed to give the Minister enough information to consider the adverse effects feared by the local interests. This information might affect the route but not the policy. The inspector was also empowered to make recommendations regarding the material properly before him.

The inspector somewhat muddied the watters by deciding that "a cardinal question in this particular inquiry was whether there existed a need for the contested sections of the new motorways". ${ }^{15}$ To help decide this (an entirely different question from routing), he held that projections of future traffic and road capacity were germane. The department entered expert evidence (largely an advisory manual) on techniques to do this. Although local intervenors were allowed to offer evidence criticizing the techniques, they were not allowed to cross-examine departmental experts on these technical points. The inspector, however, duly reported the objectors' evidence on this matter.

Between the end of the inquiry and the Minister's decision, the department released revised (lower) traffic projections which for some reason, the Minister concluded, strengthened rather than weakened the case for these sections of motorway.

The plaintiff claimed that the refusal to permit cross-examination and to re-open the inquiry to hear argument about the implications of the lower traffic forecasts constituted a breach of natural justice, and that

\footnotetext{
13. [1981] A.C. 75.

14. D.G.T. Williams, "Public Local Inquiries - Formal Administrative Adjudication" (1980) 29 Internat. Compar. L. Q.701 at 715.

15. Supra n. 13 at 113 (per Lord Edmund-Davies).
} 
therefore the Minister's decision should be quashed. The majority of the House of Lords disagreed, reasoning that a public hearing with a large number of intervenors (over 100) was different from a normal quasijudicial hearing. Lord Diplock was opposed to over-judicializing such a proceeding and rejected the assumption that oral testimony and crossexamination are the only fair way of ascertaining matters of fact and expert opinion. He conceded that an obligation of fairness rested on the department to give enough information about the reasons for the scheme so that factual accuracy or the validity of arguments could be challenged. He saw a grey area between the overall policy set by Parliament and a consideration of the exact route which was within the purview of a local inquiry. However, he seemed to believe that the traffic projections were part of the overall policy and therefore not open to challenge. As to the Minister's obligation to be quasi-judicial, the decision of whether or not to build was purely administrative. Although the Minister must ensure equal treatment for a local authority proposing a scheme and the objectors, both Lord Diplock and Viscount Dilhorne saw the department proposing the roads more as an extension of the Minister than as a party. Therefore, it appears, the Minister was entitled to accept private advice and response from his department as to the public's criticism of it.

Lord Edmund-Davies, in his dissent, was troubled by the department being put in a position to judge its own case. He saw the need for the segments of the motorway as resting on the traffic projections which were merely a technical guide, and not governmental policy. The hearing inspector had a quasi-judicial role and natural justice required the right of cross-examination on all relevant matters. It is not clear to the author how the inspector could have agreed that the need for the segments was the root issue but simultaneously have found irrelevant the arguments on traffic projection techniques upon which the finding of need rested.

The decision of the Bushell case, that evidence other than the inquiry officer's report could be considered without the need to re-open the hearing, is congruent with the Supreme Court of Canada's holding in Walters v. Essex County Board of Education. ${ }^{16}$

These examples and the Cold Lake hearings on Esso Resources Ltd.'s proposed oil sands mega project can guide us in designing an overall policy-making and approval process. First, whether or not a parliamentary debate has occurred and a general policy has emerged, local people may only feel strongly about participating when they realize that a hitherto abstract policy has local implications. Some avenue must be provided for challenges that go beyond the analogue of exact route location

16. [1974] S.C.R. 481. In this case, a Board of Education, acting as an approving authority for its own expropriation of land for a new school, received and debated in a closed committee of the whole the report of its own hearing officer. The latter had heard the appellants and had strongly advised against the expropriation. However, the Board accepted a contrary report from its solicitor without notifying the appellants of its contents.

Laskin J., speaking for the Supreme Court of Canada, held that the only duty of the Board was to "consider" the hearing officer's report. The Board was not an appeal body and its duty of fairness did not involve a duty to "hear the other side", as it was the legislature which had put it in the position of being the judge of its own case. Accepting information other than the hearing officer's report without hearing the appellants was permissible in the circumstances. 
disputes. Second, development proposals of ten arouse strong feelings. It is true that both in Cold Lake and in the Bushell case the legislative mandate should have been clearer, but the ERCB showed more flexibility and wisdom in permitting the intervenors to proceed than did the inspector, even if he was vindicated by a majority in the House of Lords. Much time and money can be saved by giving intervenors the benefit of the doubt, assuming, of course, that the regulatory body can do something with the information obtained. (Otherwise, hearing the information can mislead the intervenors by giving them false hopes of influencing the decision.) There does, however, have to be a limit and clear government policies created after full public debate would place hearing bodies on a firm footing in ruling some matters out of order.

\section{A. THE PROJECT APPROVAL SYSTEM IN ALBERTA}

It must first be observed that the Alberta EIA process and project approval rest on separate mandates and that project approval procedures differ radically for energy and non energy-related projects. Integrating these processes is a challenge. Furthermore, environmental factors are of ten to be weighed explicitly in these processes even if no EIA is required. These points must be understood for an overall appreciation of the rather complicated picture.

The formal EIA process is authorized under section 8 of the Land Surface Conservation and Reclamation Act ${ }^{17}$ which permits (not requires) the Minister of the Environment ${ }^{18}$ to require an EIA if an operation or activity is proposed which, in his opinion, will, or is likely to, result in "surface disturbance". ${ }^{19}$ The Act, and therefore this power, does not apply to subdivided land used or intended to be used for residential purposes. ${ }^{20}$ Section $8(2)$ stipulates that the report may be required to assess the impact of the operation or activity on such matters as the conservation or pollution of natural resources, noise levels and aesthetics. A

17. R.S.A. 1980 , c. L.3.

18. Under s. 10 of the Department of the Environment Act, R.S.A. 1980, c. D-19, the Minister may delegate this discretion to any departmental employee. By Ministerial Order 26/76, the authority was delegated to the Assistant Deputy Minister of the Environmental Coordination Service of the Department of the Environment.

It should also be noted that s. 13 of the same act allows the Lieutenant Governor in Council, upon the recommendation of the Minister of the Environment, to require by regulation that a Minister, government of ficial or government agency specified therein not exercise any specified power unless the Minister on the environmental advisability of the action, and unless the Lieutenant Governor in Council then consents. So far as the author is aware, however, no such regulation has ever been passed.

It should also be noted that under s. 33(2) of The Historical Resources Act, R.S.A. 1980, c. $\mathrm{H}-8$, the Minister of Culture may require an historical resource impact assessment, if he is "of the opinion that any operation or activity which may be undertaken by any person will, or is likely to, result in the alteration, damage or destruction of historic resources . . $\therefore$. After the report is submitted, the Minister may require necessary salvage preservative or protective measures before permitting the person involved to proceed with the operation or activity.

The ERCB has provided guidelines in Informational Letter IL 82-11 (Mar. 5, 1982).

19. "Surface disturbance" is defined in $\mathbf{~} \mathbf{1 ( s )}$ as, i) the disturbance, exposure, covering up or erosion of the surface of land in any manner, or ii) the degradation or deterioration in any manner of the surface of land.

20. S. 2(2). 
discussion of the economics of mitigation measures for all but aesthetics may also be required.

These, taken together, are thought by the government to authorize the detailed requirements in the guideline documents which have been released by Alberta Environment, either alone ${ }^{21}$ or in concert with the ERCB. ${ }^{22}$ We postpone for the moment the question whether section 8 actually authorizes the Minister to require such categories of information as social impact assessments which are imposed by the guidelines. ${ }^{23}$ No statutory guidance is given about how the EIA is to be used. Legislation is silent about whether the EIA statement is to accompany the proposal through the approval process for the many different permits which various projects require. Public hearings are not part of the EIA process, and none of the approval bodies are specifically enjoined to use the EIA statement. After some interdepartmental conflict about the importance of the EIA in the ERCB approval process, it has been agreed ${ }^{24}$ that the final EIA will be filed with the Board as part of the application. Even so, the breadth of its mandate to consider the contents is in question, and will be considered momentarily. One may ask whether the overall merits of the project are assessed in a holistic way. ${ }^{25}$ Of course, where the Minister of the Environment is empowered to attach environmental conditions to approvals granted by the Board ${ }^{26}$ the Minister will make extensive use of the EIA. The decision whether to approve the project is not, of course, the Minister's prerogative.

The process for approving the draft EIA is as follows. The draft is circulated to almost 20 government departments and agencies, which review it and give comments to Alberta Environment. The proponent must incorporate these comments and the document is formally reviewed. In this

21. Alberta Environment, Environmental Impact Assessment Guidelines Edmonton Land Conservation and Reclamation Division, Alberta Environment (February, 1977).

22. Alberta Environment and Energy Resources Conservation Board, Guidelines Respecting an Application to Construct or Alter an Electric Transmission Line (Guide G-22, 1981); Guidelines Respecting an Application for a Commercial Crude Bitumen Recovery and Upgrading Project (Guide G-23, 1981); Pipeline Applications to the ERCB A Guide to Content (Guide G-24, 1981); Industrial Development Permit Applications to the ERCB A Guide to Content (Guide G-25, 1981); Sour Gas Processing-Plant Applications to the ERCB A Guide to Content (Guide G-26, 1981); and Thermal Power Plant Applications to the ERCB A Guide to Content (Guide G-28, 1981).

23. Each of the documents cited in notes 21 and 22 contemplates the assessment of community, social or socio-economic factors. G-28 (thermal power plants), supra $n .22$ at p. 4, contemplates that two sets of alternative ways of melting needs be comparatively evaluated other projects and other methods. The implication is that non-project methods such as the "do-nothing" alternative should be included, and this is specifically stated in the Alberta Environment Guidelines, supra n. 21 at 1.

24. ERCB and Alberta Environment, Informational Letter IL 80-19 (July 24, 1980).

25. C. D. Hunt and A. Lucas, Environmental Regulation - Its Impact on Major Oil and Gas Projects: Oil Sands and Arctic (Canadian Institute of Resources Law 1980) 108.

26. The ERCB is obliged under several Acts (e.g., Coal Conservation Act, R.S.A. 1980, c. C14, ss. 21, 24; Oil and Gas Conservation Act, R.S.A. 1980, c. 0-5, s. 26; Hydro and Electric Energy Act, R.S.A. 1980, c. H-13, ss. 7, 9, 13; Oil Sands Conservation Act, S.A. 1983, c. 05.5, s. 12; Pipeline Act, R.S.A. 1980, c. P-8, s. 8) to refer applications to the Minister of the Environment who is empowered to impose environmental conditions on approvals which the ERCB may grant. The Board may make certain environmental regulations with the approval of the Minister of the Environment (e.g., Oil and Gas Conservation Act, supra, s. 10(2)). 
process the Natural Resources Coordinating Council may be involved if interdepartmental discussion is still needed. (This Council is established under the Department of the Environment $\mathrm{Act}^{27}$ and consists of a number of deputy ministers, the chairman of the ERCB and other representatives designated by the Lieutenant Governor in Council. Its mandate is, inter alia, to inquire into any matter pertaining to the environment and to review policies programs or procedures and report thereon.) After Alberta Environment receives the formal comments of the various departments, it reviews them and refers any unresolved matters to the relevant Cabinet committee if necessary. Finally, once the final statement has been amended accordingly, the Minister of the Environment requests Cabinet approval for the proponent to proceed to the formal permitting stage. ${ }^{28}$ (It is not clear why this Cabinet approval is legally required.) Thus, whether formally or not, whenever an EIA is required, an implicit approval-in-priniciple step is included in the process. It may also be argued that this step allows an holistic view to be taken of the project at the very highest level, although this is neither guaranteed nor done within view of the public.

The overall approval process for energy-related projects uses a well developed "single-window" approach through the ERCB whose mandate rests on several statutes. In some cases, such as coal mines, the process begins with a formal "initial disclosure" to the government, which requires approval-in-principle by Cabinet. ${ }^{29}$ Following this, a formal application is submitted to the ERCB, which will circulate it to interested departments. ${ }^{30}$ Provisions exist for public hearings ${ }^{31}$ to be held by the ERCB and public interest groups, as well as local intervenors with pro-

27. R.S.A. 1980 , c. D-19, s. 11.

28. M.E. Gordon, The ERCB: Its Environmental Role and Relationships (Environment Council of Alberta Draft Report, 1984) 46.

29. C. D. Hunt and A. R. Lucas, Canada Energy Law Service 30-3073-S. (Throughout this article, all references to this service should be assumed to include the preface 30 before the page number.).

30. Not only the Minister of the Environment but various ministers including the Minister of Energy and Natural Resources (e.g., Pipeline Act, supra n. 26, s. 8, Hydro and Electric Energy Act, supra n. 26, s. 7); the Associate Minister of Public Lands and Wildlife (e.g. Hydro and Electric Energy Act, supra n. 26, s. 13; Oil Sands Conservation Act, supra n. 26, s. 14(3)); Oil and Gas Conservation Act, supra n. 26, s. 14.1; the Minister of Utilities and Telephones (Pipeline Act, supra n. 26, s. 9); or the Minister of Transportation (Pipeline Act s. 39) may have the power to approve or attach conditions to ERCB approvals.

31. Hearings are usually discretionary when the Board is considering any order or direction (Energy Resources Conservation Act, R.S.A. 1980, c. E-11, s. 29(1)), although any person whose rights may be adversely affected by the board's decision has the right to notice and a reasonable or adequate opportunity to learn the facts, to furnish relevant evidence and to make argument. This does not necessarily, however, imply a hearing (ss. 29(2) and (3)). Sometimes persons affected can requisition a hearing (s. 43). Legislation may prescribe a public hearing or the obtaining of views on development proposals in other suitable ways (e.g. Oil Sands Conservation Act, supra n. 26, s. 19(4)). The predecessor section of the Oil and Gas Conservation Act, supra n. 26, s. 31(5) required a hearing. The terms "hearing" and "public hearing" are here treated synonymously, as they were in Athabasca Tribal Council v. Amoco Canada Petroleum Company Ltd. [1980] 5 W.W.R. 165 (Alta.C.A.); explicitly by Laycraft J.A. at 167-68 and implicitly in the Supreme Court (per Ritchie J. [1981] I S.C.R. 699, p. 702). For all major proposals, the ERCB exercises its discretion in favour of holding hearings (Hunt and Lucas, supra n. 29, at 3065-6, in regard to hydro development but the point is generally accepted). 
perty interests, are often heard. Only the latter, however, can qualify to receive an award of costs. ${ }^{32}$

Past efforts to integrate environmental and social impact assessment into the approval process have included ad hoc appointments of the Deputy Ministers of Environment and Municipal Affairs to the ERCB panel hearing the application and the decision to require acceptance of the final EIA by the Minister of the Environment prior to formal application to the ERCB for approval. As well, representatives of the Department of the Environment have been permitted extensive rights of crossexamination. Also, recent major hearings have seen a consolidated government position represented by a Crown counsel. This approach, of course, could lead to a "lowest common denominator" position which ignores the concerns of such agencies as Fish and Wildlife or Environment (or any other perspective, for that matter). Board guidelines require the inclusion of biophysical and social information in applications for sour gas processing plants, commercial crude bitumen recovery and upgrading projects and industrial development permits. ${ }^{33}$

Parenthetically, it may be noted that the attempt to ensure an overall "one-window" type of hearing for energy projects has met with mixed reviews. Apparently some permanent ERCB members are not convinced that ad hoc members fully appreciate the unique responsibilities of the Board. Perhaps these acting members find themselves torn between the interest of their own department and the responsibilities of the Board. It seems that similar ad hoc appointments may be rare in future. ${ }^{34}$

Following the hearing, the Board deliberates and then issues a report. Sometimes it is empowered to issue the approval itself, ${ }^{35}$ but other times it can only recommend and the final decision is made by the Lieutenant Governor in Council ${ }^{36}$ (Cabinet) or even the Legislature. ${ }^{37}$ To some degree, which we will examine shortly, the ERCB can impose environmental conditions separate from those set by the Minister of the En-

32. See Energy Resources Conservation Act, R.S.A. 1980, supra n. 31, s. 31, the Local Intervenors' Costs Regulation Alta. Reg. 517/82 and ERCB Guidelines Respecting Applications for Local Intervenors' Costs Awards Guide G-31, (December 1982). It should be noted, however, that the ERCB decision interpreting the Guidelines to this ef fect (Decision D83-8, see Hunt and Lucas supra n. 29, at 5151-60) has been upheld on appeal (A/berta Fish and Game Association v. ERCB, unreported, 14 January 1985, No. 16982 (Alta. C.A.)).

33. Guides G-23, 25 and 26, supra n. 21.

34. Gordon supra n. 28 at 10.

35. Oil and Gas Conservation Act, supra n. 26, ss. 14, 26, 30(2); Coal Conservation Act, supra n. 26, ss. 10, 11, 23; Pipeline Act, supra n. 26, s. 11; Hydro and Electric Energy Act, supra n. 26 ss. $5,12,24(1)$.

36. Coal Conservation Act, supra n. 26, ss. 24(3) (for coal mines producing more than 45,000 tonnes per year), 28 and 29 (1) (operation of a power plant using more than 230,000 tonnes per year); Oil and Gas Conservation Act, supra n. 26, s. 30; Oil Sands Conservation Act, supra n. 25, ss. 7, 10(3), 11(3), 13(3), 19(5); Hydro and Electric Energy Act, supra n. 25, ss. $8,9(1)$.

37. Hydro and Electric Act, supra n. 26, s. 7. Note, however, that s. 3(1) allows the Board by regulation to exclude a hydro development, power plant, transmission line or electric distribution system from any provision of the Act or regulations. 
vironment. The Lieutenant Governor in Council may approve or veto conditions set by that Minister or the ERCB and set additional ones. ${ }^{38}$

Once the energy project has received this formal approval, the proponent then enters the permit or licence phase. Various acts may require permits to build or licences to operate, to enter the land or use the water. ${ }^{39}$ At this stage detailed engineering drawings and process information may be required. ${ }^{40}$

\section{B. THE BREADTH OF THE EIA MANDATE}

Illuminating general descriptions of the overlapping environmental mandates of the Department of the Environment and the ERCB have already been done by Hunt and Lucas ${ }^{41}$ and there is no point in repeating them. There is no doubt that both the mandates and the interpretation of them have evolved. Subject to the criticism about the lack of a forum for strategic planning issues, there has been a workable division of responsibilities between the two sets of EIA mandates and consequent approval conditions. Although the Board "has responsibilities for assisting the Government in control of pollution from energy resource development" and must consider how proposed environmental protection measures will affect other aspects of its mandate such as energy resource conservation and efficiency, "it is not the proper authority to make final determinations respecting environmental impact, standards or reclamation ... such determinations are the responsibility of the Department of the Environment . . ". .42 The Board expresses its preference for such things as choice of water supply but the Minister of the Environment makes the decision and attaches conditions accordingly.

What we want to do is assess whether either the Department or the Board has the authority to impose the types of impact assessment requirements that they do. In the author's opinion they have both exceeded their mandates.

\section{Alberta Environment's Mandate}

Let us examine first Alberta Environment's legal authority, as found in the Land Surface Conservation and Reclamation Act (LSCR Act) and the Department of the Environment Act. ${ }^{43}$ In this section, it will be

38. See, e.g., Coal Conservation Act, supra n. 26, ss. 24(4) and 30(f); Oil and Gas Conservation Act, supra n. 26, ss. 8(1), 14(2), 26(4); Oil Sands Conservation Act, supra n. 26, ss. 6, 10(4), 11(4), 13(6), 19(6); Hydro and Electric Energy Act, supra n. 26, ss. 8(2), 9(4), 18(3).

39. See, e.g., Clean Air Act, R.S.A. 1980, c. C-12, ss. 3 and 4; Clean Water Act, R.S.A. 1980, c. C-13, ss. 3 and 4; Land Surface Conservation and Reclamation Act, supra n. 17, ss. 24,25; Mines and Minerals Act, R.S.A. 1980, c. M-15; ss. Public Lands Act, R.S.A. 1980, c. P-30, s. 19(1); Surface Rights Act, S.A. 1983, c. S-27.1, ss. 12, 13, 15; Water Resources Act, R.S.A. 1980, c. W-5, ss. 5(1), 11(1).

40. See the following Acts, or regulations thereunder:

Clean Air Act, supra n. 39; Clean Water Act, supra n. 39; Coal Conservation Act, supra n. 26; Land Surface Conservation and Reclamation Act, supra n. 17; Oil and Gas Conservation Act, supra n. 26; Pipeline Act, supra n. 26.

41. Supran. 25 at 101-8 and note 29 at p. 30-3014.

42. Hunt and Lucas, supran. 29 at 3080 and 3051 , quoting the Board's own words.

43. Supra n. 17, R.S.A. 1980 , c. D-19. 
argued that the Minister's power to require impacts to be assessed is limited to those kinds specifically mentioned in sections $8(2)$ and $8(3)$ of the LSCR Act. To the extent that regulations promulgated under the Act purport to extend this list, they are ultra vires. It will also be submitted that the Department of the Environment Act does not help expand the Minister's power to require applicants to carry out other kinds of impact assessment, even if he is himself authorized to assess the economic impacts of proposed projects. Furthermore, the Minister's approval or acceptance of the EIA may not be a legal prerequisite to entering the energy project approval process administered by the ERCB. Lastly, it will be argued, the royal prerogative cannot be invoked in aid of these ultra vires impact assessment requirements, since the various statutes involving the approval process have exhaustively defined the powers of the regulators.

The discussion will be facilitated if sections $8(1)$ and $8(2)$ of the LSCR Act are set out in full:

$8(1)$ When any person proposes to undertake any operation or activity and, in the opinion of the Minister, the operation or activity will result or is likely to result in surface disturbance, the Minister may order that person to prepare and submit to the Minister in the time prescribed in the order, a report containing an assessment of the environmental impact of the proposed operation or activity if the Minister considers it in the public interest to do so.

(2) An order of the Minister under subsection (1) may require that the report contain an assessment of the impact of the proposed operation or activity on all or any of the following:

(a) the conservation, management and utilization of natural resources;

(b) the prevention and control of pollution of natural resources;

(c) the prevention of noise and the control of noise levels resulting from the operation or activity in so far as they affect the environment in the vicinity of those operations or activities;

(d) economic factors that directly or indirectly affect the ability of the applicant to carry out measures that relate to the matters referred to in clauses (a), (b) and (c);

(e) the preservation of natural resources for their aesthetic value.

Also, the Minister may under section 8(3) require that the report "show any alternative means by which the proposed operation or activity could be carried out".

Although the provisions of section 8 first appeared when the LSCR Act was passed in 1973, the overall act had its genesis in the Surface Reclamation Act of $1963 .{ }^{44}$ This act was directed toward the reclamation of, and the recovery of rental for, the surface of land used for mines, quarries, oil and gas operations and pipelines.

The 1963 act was entirely ineffective and due to public outcry beginning in 1969, the Minister of the Environment in 1971 directed the new Environment Conservation Authority (ECA) to hold public hearings on the subject. ${ }^{45}$ The LSCR Act was passed in 1973 and took account of the general thrust of the ECA's report. The ambit of the LSCR Act is broad enough to include virtually all surface disturbance, except that agricultural operations and land subdivided for residential purposes are specifically exempted from its provisions. Almost all of the Act deals

44. S.A. 1963, c. 64 .

45. See P.S. Elder, "The Participatory Environment in Alberta" (1974) 12 Alta. L. Rev. 403. 
with the approval process for, and the regulation of, surface operations and the reclamation of the land concerned after completion of the operation.

The Act, then, was not primarily designed as a vehicle for overall EIA procedures in the province. It seems very definitely to have a physical, not a socio-economic, orientation. Although a project's impact on the "conservation, management and utilization of natural resources" may be assessed, it is hard to see how this can be elevated to any adequate socio-economic assessment. The impact of the project on private, not public, economics is to be assessed. Noise and aesthetics are clearly relevant items for consideration, but both of these go to the enjoyment of the natural, not the socio-economic environment.

The author has therefore concluded that, prima facie, socio-economic assessment is not among the categories of "environmental impacts" the Minister can require to be done under section 8. Although there is no statutory definition of environmental impact, or of environment, we have no reason to think that social or economic environments are included in these terms.

Ministers of the Crown must be able to cite some kind of legal authority when they impose requirements on applicants for governmental approval. When a well defined approval process exists under Alberta's energy statutes, it is self-evident that the Minister of the Environment would not have the right to impose EIA requirements in the absence of section 8 of the LSCR Act or some equivalent legislation.

We have concluded that socio-economic impact assessment is not specifically covered in section 8 of the LSCR. Invoking the well known expressio unius principle of statutory construction ${ }^{46}$ we could also conclude that the Minister cannot require the assessment of any factor other than those listed in sections 8(2) and 8(3). To include certain requirements is to exclude others. This would exclude social impacts, the "do-nothing" alternative, a discussion of alternative operations or activities, or even a justification of the project unless these are required as part of the license or permit process under other legislation or regulations.

Where, then, could authority to require such contents be found? The Act defines "natural resources" to mean "land, plant life, animal life, water and air" , 47 but this does not help to enlarge the mandate.

Possibly section 8(4) of the LSCR Act augments the Minister's powers to require items to be included:

A report under subsection (1) shall be prepared and submitted in accordance with the regulations or, in the absence of the regulations, in accordance with the directions of the Minister.

As regulations have been made ${ }^{48}$ no directions of the Minister can be issued, at least in respect of the types of projects covered by them (coal,

46. See P. St. J. Langan, Maxwell on the Interpretation of Statutes (12th ed. 1969) 293.

47. Supra n. 17, s. 1(m).

48. See infran. 51 . 
oil and gas pipelines and oil sands). Section 11 of the Act permits the Lieutenant Governor to make regulations ${ }^{49}$

(a) providing for any matter necessary to carry out the provisions of this Act or to meet cases that may arise and for which no provision is made by this Act (my emphasis).

The first part of the subsection does not expand the list of impacts which may be required under section $8(2)$ but the italicized part could be interpreted to permit this. If the exclusionary rule of statutory construction is applied to sections 8(2) and (3) however, then the statute has spoken. Provision has been made for the relevant "cases" in section 8 . It has implicitly excluded any further contents and such regulations, extending EIA contents beyond those provided, would be ultra vires.

The courts have used the purpose sections of statutes to reduce apparently broad mandates to promulgate regulations or to make decisions. If the purpose of a statute is being subverted or exceeded by a discretionary power it purportedly gives, the action is ultra vires. ${ }^{50} \mathrm{Here}$, there is no indication that the purpose would be frustrated by the requirements, but it is hard to turn an Act concerned with land surface reclamation and conservation into a vehicle for considering social impacts. All statutes are ultimately about human welfare or obligations and rest on some implicit notion of basic ends, but their purposes are almost always seen in operational rather than strategic or philosophic terms.

A number of such, arguably, ultra vires regulations have been promulgated, which create certain operations as "Regulated Surface Operations" and specify that before their construction or operation, inter alia, an application must be made for a Development and Reclamation Approval. ${ }^{51}$ These provisions on their own would be unexceptionable. Such application, however, must include a development report as defined in the Land Conservation Regulations. ${ }^{52}$ This report "shall normally" include a discussion of such matters as residential development, aesthetic and scenic considerations, active or passive outdoor recreation areas, existing agricultural, commercial and industrial developments, proposed transmission and transportation facilities, and housing requirements, including physical and social infrastructure (schools and hospitals). The author believes that most, if not all, of these requirements are ultra vires.

The approving authority for the Development and Reclamation Approval is usually the Minister of the Environment, although certain

49. Supra n. 17, s. 11(a).

50. See, inter alia, the locus classicus in England, Padfield v. The Minister of Agriculture [1968] A.C. 997 (frustrating the purpose); Re Multi-Malls Inc. and Minister of Transportation and Communications (1976) 14 O.R. (2d) 49, (matters collateral or extraneous to the Act) (leave to appeal to the Supreme Court of Canada refused Oct. 13, 1976, 12 N.R. 179); Brampton Jersey Enterprises Ltd. v. The Milk Control Board of Ontario [1956] O.R. 1 (C.A.) (matters extraneous or collateral to the Act, applying the ejusdem generis rule); $R e$ Heppner and the Minister of the Environment for Alberta (1978) 80 D.L.R. 3(d) 112 (Alta. S.C. App. Div.) (ultra vires regulation).

51. See the Regulated Coal Surface Operations Regulations, Alta. Reg. 170/74 as am.; The Oil and Gas Pipeline Surface Operation Regulations, Alta. Reg. 207/76 as am.; and the Regulated Oil Sands Surface Operation Regulations, Alta. Reg. 159/76 as am.

52. Alta. Reg. 125/74, s. 25. 
powers may be, and have been, delegated to the Chairman of the Land Conservation and Reclamation Council. ${ }^{53}$

Thus it is doubtful that section 8 of the LSCR Act permits the requirement of social impact assessment or anything else not covered in sections $8(2)$ and (3). Of course, much specific information relevant to environmental impact may be required under various acts or regulations at the licence or permit stage, ${ }^{54}$ and it is not proposed here to challenge the vires of such provisions.

Perhaps in some ways the Department of the Environment Act may be seen as "the umbrella legislation" ${ }^{55}$ It does not appear, however, that the general power given to the Minister of the Environment in section $7(\mathrm{~h})$ of this act to "do any acts he considers necessary to promote the improvement of the environment" will help here. Under that Act, ${ }^{56}$ "matters pertaining to the Environment" are the same as those listed in section $8(2)$ of the LSCR Act, as well as operations or activities which may adversely affect the quality or quantity of any natural resource and laws "in force in Alberta that relate to or directly or indirectly affect the ecology of the environment or natural resources". The question is, however, whether any law in Alberta permits such matters as social impacts to be required in an EIA, as no statutory definition in Alberta includes them in environmental matters.

It may be worth noting that section 7 of the Department of the Environment $\mathrm{Act}^{57}$ requires the Minister to "compile, study and assess information directly or indirectly related to matters pertaining to the environment" to help improve the discharge of ministerial responsibilities. It also allows the Minister to carry out research on matters pertaining to the environment (as defined in section 2) and to conduct economic analysis, inter alia, to determine the costs and benefits of proposed major alterations of the environment. Even if social impact assessment is indirectly related to the environment or is part of a cost benefit study, however, these provisions do not authorize the Minister to impose these tasks on an applicant for approval.

Room for doubt also exists about the administrative requirement that the contents of an EIA report must be approved by the Minister before it can be submitted to the ERCB (whose power to require or to consider such aspects as socio-economic impacts can also be questioned). Presumably, the Minister's assumed power to require amendments and to approve an EIA ${ }^{58}$ must be based somewhere in the LSCR Act or in valid regulations thereunder, unless the general power in the Department

53. Regulated Coal Surface Operations Regulations, supra n. 51, s. 4 and 12; Regulated Oil and Gas Pipeline Surface Operation Regulations, supra n. 51, ss. 3 and 9(1); Regulated Oil Sands Surface Operation Regulations, supra n. 51, ss. 5(2) and 13.

54. See, e.g., the acts cited supra notes 38 and 39.

55. Wimpey Western Ltd. and W-W-W Developments Ltd. v. Director of Standards and Approvals of the Department of the Environment (1982) 37 A.R. 303 (Alta. Q.B.) per Kryczka J. at 311 .

56. Supran. 43, s. 2.

57. Supra n. 43.

58. See text preceding note 28 . 
of the Environment $\mathrm{Act}^{59}$ to do any acts to promote the improvement of the environment can be invoked. Nothing can be found, however, to base any such powers regarding the socio-economic part of the EIA.

Section 13 of the Department of the Environment Act empowers the Lieutenant Governor in Council to require by regulation that government officials not exercise any specified power until the Minister of the Environment has first reported on the advisability of the action. having regard to its possible effects on the environment. No such regulations, however, have been passed.

\section{The ERCB Mandate}

Three of the ERCB's guides published jointly with Alberta Environment $^{60}$ state that all applications for permission to construct electric transmission lines, industrial developments or sour gas plants respectively, must include biophysical and social information, and that some may require an EIA. Further, Guide G-28 on thermal power plant applications stipulates that the environmental information required is to be read as including "both biophysical and social aspects of the environment" .61 From where does the ERCB derive its power to require social information and to consider it in deciding whether to grant approval for these projects?

Ignoring the problem of overlap with Alberta Environment, the general purpose sections and other general powers in various energy acts clearly contemplate some kind of ERCB environmental mandate at least "to control pollution" and in most cases "to ensure environment conservation'"62 in the drilling of wells, the development of oil, ${ }^{63}$ coal, ${ }^{64}$ oil sands ${ }^{65}$ hydro energy and the generation, transmission and distribution of electric energy. ${ }^{66}$ As well, purposes of several acts include the ensuring of "environment conservation". Further, the Board is clearly to consider the "public interest" either in its approvals" tions. 68

Other sections give the Board the power or duty to "make any investigations or inquiries and hold any hearings it considers necessary or desirable" 69 or to "make any just and reasonable orders or directions

59. Supra n. 43, s. 7(h). See discussion accompanying note 22.

60. Guides G-22, at 5, G-25, at 9, and G-26, at 4, supran. 22.

61. Id. at 9.

62. Energy Resources Conservation Act supra n. 32, s. 2(d).

63. Oil and Gas Conservation Act, supra n. 26, s. 4(f). The section does not mention environment conservation.

64. Coal Conservation Act supra n. 26, s. 4(3).

65. Oil Sands Conservation Act supra n. 26, s. 3(e). The Section does not mention environment conservation.

66. Hydro and Electric Energy Act supra n. 26, s. 2(e).

67. E.g., Coal Conservation Act supra n. 26, ss. 4(c), 14(2) and 29(3); Hydro and Electric Energy Act supra n. 26, ss. 16, 29; Oil and Gas Conservation Act supra n. 26, ss. 4(c), 30(6); Oil Sands Conservation Act supra n. 26 s. 3(b) and (g).

68. Energy Resources Conservation Act supra n. 32, s. 22(b).

69. Oil and Gas Conservation Act supra n. 26, s. 10(2), Oil Sands Conservation Act supra n. 26, ss. 5 and 6. 
that may be necessary to effect the purposes of this Act . ." ${ }^{70}$ Thus the purposes of the Act will be of great importance.

Given the possibility of combining two or more of these general and particular sections in the Energy Resources Conservation Act (E.R.C. Act) and the statutes on specific resources, ${ }^{71}$ it can be strongly argued that environmental impact assessment could be required and considered by the Board. Given the mandate of the Department of the Environment, however, the overlap leaves commentators somewhat equivocal on this point. Hunt and Lucas, for example, state that the Board analyzes and concludes environmental matters closely connected to energy, technical and economic questions (such as water supply, plant and cooling pond location). ${ }^{72}$ Presumably conflicts of jurisdiction with Alberta Environment are avoided by leaving more general matters of air and water quality and noise to the Department. ${ }^{73}$

The Board itself in fulfilling its environmental responsibilities believes it must consider how proposed measures for protecting the environment will affect energy resource conservation as well as efficiency, safety and economy of energy resource development. ${ }^{74}$ This of fers us a clue, for this formulation stresses the environment's impact on energy rather than the other way around. Perhaps this is why the Board has taken a modest view of its mandate in saying that: ${ }^{75}$

... it is not the proper authority to make final determinations respecting environmental impacts, standards or reclamation ... . such determinations are the responsibility of the Department of the Environment ... .

It was in this same application, however, that the Board declined to make a determination of the source of the water supply, one of the items Hunt and Lucas point out has been considered within its jurisdiction. ${ }^{76}$

The ERCB's authority to consider cost-benefit and social impact data, which Alberta's coal policy requires be filed with the Board, is not clear. ${ }^{77}$ Interestingly, the Board in the Esso Resources application of 1979 ruled that it lacked the authority to rule on these matters, ${ }^{78}$ but it invoked its general power under section 22 of the ERC Act:

(a) to make inquiries ... and

(b) recommend to the Lieutenant Governor in Council any measures it considers necessary or advisable in the public interest related to the ... production, development .

... of energy resources....

70. Coal Conservation Act supra n. 26, s. 7 (emphasis supplied).

71. In Esso Resources' Cold Lake application, the Board combined specific sections of the Oil and Gas Conservation Act and the Coal Conservation Act with s. 22 of the Energy Resources Conservation Act.

72. Hunt and Lucas supra n. 29, at 3068.

73. Id. at 3068 and 3080.

74. Id. at 3080 . For an interesting account of how the Board's solicitors see its environmental and socio-economic mandates, see Michael J. Bruni and keith F. Miller, "Practice and Procedure Before the Energy Resources Conservation Board” (1982) 22 Alta. L. Rev. 79.

75. Reasons of the Board in October 1979, regarding Esso Resources' Cold Lake application (quoted in Hunt and Lucas supra n. 26, at 3051).

76. See text accompanying n. 69.

77. Hunt and Lucas, supra n. 29 at 3068.

78. Id. at 3052. 
Under this section, the Board heard evidence and made recommendations. Could it do even this?

In Athabasca Tribal Council v. Amoco Canada Petroleum Company Ltd., ${ }^{79}$ Laycraft J.A. clarified the matter, subject to our discussion of the Supreme Court of Canada's ultimate ruling. In this case the Athabasca Tribal Council requested the ERCB to require, as a condition of approval for the proposed Alsands synthetic crude oil mega-project, af firmative action programs to help the development of native businesses and employment in the region. The ERCB ruled that it lacked jurisdiction and the tribal council appealed on questions of jurisdiction to the Court of Appeal.

The majority of the Court of Appeal held that the Board did not have jurisdiction, on the basis that the purpose of the affirmative action program proposed was to solve a pre-existing social problem, not one which arose as a direct impact of the project. In making this useful distinction, Laycraft J.A. said that the "board was inevitably faced with a consideration of the social and economic impact on the area". ${ }^{80}$ In considering social problems expected as a direct impact of the project, Laycraft opined that it was acting within its jurisdiction. ${ }^{81}$ Thus, for Alberta's Court of Appeal, the ERCB did have jurisdiction to hear evidence on social impacts directly attributable to the project and either prescribe conditions or, in certain cases, make recommendations to the Lieutenant Governor in Council. Whether the Board has the jurisdiction to make recommendations on pre-existing social problems not attributable to the project, however, Laycraft refused to decide. ${ }^{82}$

Whether the Supreme Court of Canada, ${ }^{83}$ in upholding the Court of Appeal's judgment, accepted the distinction between pre-existing and attributable social impacts is of considerable importance. As will be shown, its rejection leads to an extraordinary narrowing of the jurisdiction both of the Board and the Lieutenant Governor in Council.

The Supreme Court unanimously accepted the Court of Appeal's decision that, in the circumstances described above, the ERCB lacked jurisdiction to prescribe affirmative action. Ritchie J. speaking also for Laskin, then C.J.C., and Dickson and McIntyre J.J. did "not find any error in the judgment of the Court of Appeal". ${ }^{84}$ Hardly a ringing endorsement of the Court of Appeal's reasons for judgment, although later "in the result" he said that he did agree with them. ${ }^{85}$ Lamer J. for the rest of the Court, "for the reasons given by" Ritchie, also agreed there was no error in the judgment. ${ }^{86}$

\footnotetext{
79. [1980] 5 W.W.R. 165 (Alta. C.A.).

80. Id. at 175 .

81. Id. at 176.

82. Id. at 177 .

83. [1981] I S.C.R. 699.

84. Id. at 708 .

85. Id. at 712 .

86. Id.
} 
It may seem unduly literal to cavil at these phrases, but the Supreme Court was narrower in its reasoning than the Court of Appeal. ${ }^{87}$ Justice Ritchie said that the "powers with which the Board is endowed are concerned with the natural resources of the area rather than with the social welfare of its inhabitants" ${ }^{88}$ Although in the same sentence he seemed to accept Laycraft's distinction when talking of "the age-old disadvantages" of the native people, his next paragraph seems unequivocally to reject ERCB jurisdiction on directly attributable social impacts: ${ }^{89}$

\footnotetext{
It is however true that the expenditure of four billion dollars in the creation of a new town and a new industry undoubtedly present new problems for these people and it may well be that some form of legislation could be devised and adopted to meet their needs. No such legislation appears to have been enacted in Alberta and in my opinion it is no compensation for this lack of authority to seek to apply legislation designed for the conservation of energy resources to the amelioration of social problems (my emphasis).
}

Nor did any mention of the public interest persuade him. It did not support the interpretation that "enabling statutes which are exclusively concerned with the development of "energy resources and energy" "so were intended by the legislation to "endow the Board with authority to recommend measures directed towards the development and control of the social welfare of the Indian people". ${ }^{91}$

In the light of the holding of both courts that the impacts concerned extended beyond those imposed by the Alsands project, ${ }^{92}$ the Supreme Court's formulations about project related impacts are dicta. Nevertheless, their unnecessary narrowness is of concern and it is to be hoped that future courts can be led to accept Laycraft's broader view. The narrower view would imply that the ERCB enjoys little, if any, mandate to make approval conditions regarding social impacts and a fortiori cannot require or hear evidence for these purposes. We must recall, however, that the narrow formulation of the purpose sections and Board mandate was in the context of rejecting jurisdiction over social impacts and not environmental impacts. The Athabasca case did not consider the several references in the purpose sections of pollution control and environment conservation. In the relevant case these would have to be given some meaning in conjunction with the general powers which were limited in Athabasca by the lack of reference in the purpose sections to social impact. Thus the case is distinguishable for jurisdiction over environmental (biophysical) impacts.

Similarly with cost-benefit analysis. Several purpose sections refer to "the economic, orderly and efficient development and operation in the

87. Hunt and Lucas supra n. 29 at 3015.

88. Supra, n. 83 at 708 .

89. Id.

90. Id. at 709 .

91. Id.

92. Morrow J.A. in dissent argued that the approval conditions requested by the appellant contemplated amelioration of impacts attributable to the project (supra n. 79 , at 184-5). Although the Oil Sands Conservation Act S.A. 1983 (Fall session), c. O-5.5 has been passed since Athabasca, the language of the former would have to be strained considerably to affect the above discussion of this case. 
public interest"93 of various resources. Surely these, when combined with the Board's general powers in considering an application to make inquiries into any matter within the purview of the acts which it administers, ${ }^{94}$ adequately found ERCB jurisdiction to consider cost-benefit analysis.

Athabasca does not directly address whether the ERCB has jurisdiction to recommend to the Lieutenant Governor any social measures it considers necessary but cannot itself impose. The question may be whether the Lieutenant Governor in Council's (Cabinet's) weighing of energy applications is limited by the purpose sections in the same way as the Board's clearly is. If so, perhaps it cannot require (by regulation ${ }^{95}$ or otherwise), or use, social impact analysis either. In that case, the Board could certainly not advise it on these forbidden matters. On the other hand, if Cabinet has a broader mandate to consider the whole sphere of provincial policy, section 22 of the ERC Act could be argued to allow the Board to give advice on any measures "it considers . . . advisable in the public interest related to" energy if they were within Cabinet's jurisdiction, although not within its own, to impose. Whether it is the most suitable body to do so is, of course, another matter.

In reply, it may be argued that the Legislature meant for the ERCB to have the power to advise the Lieutenant Governor in Council on matters within the Board's own mandate, and that other sources are responsible for giving social impact advice. But as we have seen, ${ }^{96}$ it is doubtful that the EIA statement process mandates the consideration of such matters. Yet apart from the EIA and the ERCB hearing, from whence is the Cabinet to receive sustained social impact analysis?

Although the exercise of a prerogative power is not per se reviewable, ${ }^{97}$ a statutory power exercised by the Governor (or Lieutenant Governor) in Council is. ${ }^{98}$

\section{Law and jurisdiction are within the ambit of judicial control and the courts are entitled to see that statutory procedures have been properly complied with. ${ }^{99}$}

Nevertheless, when the statute contemplates that matters of public convenience and general policy are involved in the Governor in Council's decision, it is "final and not reviewable in legal proceedings." 100 It is arguable that the energy legislation contemplates that the Lieutenant Governor in Council take such a broad view (otherwise Cabinet's decision to freeze approval on the Cold Lake megaproject until the federal

93. Hydro and Electric Energy Act R.S.A. 1980, c. H-13, s. 2(c). Sec also Coal Conservation Act R.S.A. 1980, c. C-14, s. 4(c); Oil and Gas Conservation Act R.S.A. 1980, c. O-5, s. 4(c).

94. E.g., Energy Resources Conservation Act R.S.A. 1980, c. E-11, s. 22.

95. Canadian Pacific Railwayv. R. (1906) 38 S.C.R. 137.

96. See text accompanying n. 43-55.

97. Re Doctors Hospital and Minister of Health et al. (1976) 68 D.L.R. (3d) 220 at 230 (Ont. H. Ct. Div.) Re Multi-Malls Inc. and Minister of Transportation and Communications supra n. 50 (Ont. C.A.)

98. Irving Oil et al. v. National Harbours Board (1983) 46 N.R. 9195 (S.C.C.). See also Re Doctors Hospital and Minister of Health et al. supra n. 97.

99. Id.

100. Irving Oil Ltd. v. National Harbour Board supra n. 98 at 95. 
and provincial governments reached an energy agreement was clearly ultra vires), and that therefore it could ask any agency to provide socioeconomic or indeed any other kind of relevant input.

It is submitted that the Lieutenant Governor in Council is clearly exercising a statutory, not a prerogative power. Indeed, the author is not aware of any claim to the contrary. But, suppose that the claim were made. Although crown prerogative is distributed between the central Parliament and provincial legislatures in a manner which accords with the distribution of legislative powers, ${ }^{101}$ the prerogative involved here would have to rest on Crown ownership of land. Yet the energy statutes of the province set up a universal approval scheme regardless of whether private or public land is involved. Thus, the statutes may have emasculated the ownership prerogative.

It is . . . certain that if the whole ground of something which could be done by the prerogative is covered by the statute, it is the statute which rules. . . . Inasmuch as the Crown is a party to every Act of Parliament it is logical enough to consider that when the Act deals with something which before the Act could be affected by the prerogative, and specifically empowers the same thing, but subject to conditions, the Crown assents to that, and by that Act, to the prerogative being curtailed. ${ }^{102}$

If one takes the prerogative powers residing in the Crown at any moment and contrasts then with the legislative sovereignty of parliament, it is possible to argue that as legislation grows the prerogative recedes. ... When the above prerogatives are exercised, the Crown . . . is invoking the residue of its once very extensive personal powers, these powers having been curtailed and limited whenever the legislature has directed other modes for their exercise in statutes. ${ }^{103}$

If this is correct, surely statutes in Alberta have covered the whole ground.

First, there are the energy related statutes which have been the subject of this article. Second, subsection 2(2) of the Public Lands Act says that: ${ }^{104}$

All public land is under the administration of the Minister (the Associate Minister of Public Lands and Wildlife) except that public land that is, by virtue of any other Act or an order of the Lieutenant Governor in Council, under the administration of another Minister of the Crown or of a Crown Corporation.

Public land is "land of the Crown in right of Alberta"'.105 Thus, we irresistibly conclude that no provincial Crown land in Alberta is subject to direct control by the Lieutenant Governor (who would exercise that control, of course, on advice from Cabinet). In turn, this could imply that his jurisdiction to approve energy projects is limited by the same statutes as the ERCB. If this is correct, the Lieutenant Governor in Council has only the authority found in the energy related statutes to impose binding conditions on energy projects in order to ameliorate social impacts.

The Mines and Minerals Act is a further incursion into the direct control of Crown lands by the Crown. That act applies: ${ }^{106}$

101. Her Majesty in Right of Alberta v. Canadian Transport Commission [1978] I S.C.R. 61 at 71 (per Laskin C.J.C.).

102. Attorney-Generalv. De Keyser's Royal Hotel [1920] A.C. 508, per Lord Dunedin at 526.

103. W.H. McConnell, Commentary on the British North America Act (Toronto: Macmillan of Canada, 1977) pp. 30-31. McConnell, however, cites no authority for this statement.

104. R.S.A. 1980 , c. P-30 (words in brackets supplied).

105. Id.s. I(p).

106. R.S.A. 1980 , c. M-15, s. 2. 
a) to all mines and minerals and related natural resources vested in or belonging to the Crown in right of Alberta, and

b) where the context so permits or requires, to all wells, mines, quarries and minerals in Alberta.

Mines and Minerals are defined in the Act to include hydrocarbons and oil sands projects. ${ }^{107}$ Other provisions of this Act bolster the argument that the ownership prerogatives of the Crown have been displaced by statute. For example, several sections ${ }^{108}$ allow the Minister of Energy and Natural Resources to grant leases and give him the power to prescribe their form, or to attach conditions. Further, the Lieutenant Governor in Council may make regulations governing leases or lesser interests of oil sand rights ${ }^{109}$ and petroleum and natural gas rights ${ }^{110}$ or respecting, inter alia, the working and development of any minerals."11 Section 16 prohibits minerals belonging to the Crown from being sold "unless the sale is specifically authorized under an Act of the Legislature". Finally, section $11^{112}$ forbids any disposition of an estate in a mineral owned by the Crown unless it is specifically authorized by statute.

If no social impact type of terms and conditions are in a lease, the leaseholder, as any property owner, can exercise his or her property rights unless statute-based limitations are imposed. The bare prerogative would simply not suffice. The Lieutenant Governor in Council has been given the power to make regulations governing leases etc., but so far as the writer is aware, neither leases nor regulations under the Mines and Mineral Act contain conditions designed to ameliorate social impact. Even if they did, one would have to infer quite broad social purposes of this Act from its overall provisions (it contains no purpose section) in order to argue their vires. If regulations were to be passed under other energy statutes, they would have to run the Athabasca gauntlet regarding the purposes of these acts.

Perhaps the main barrier to a conclusion that the prerogative has been ousted in this area is section 14 of the Alberta Interpretation Act, ${ }^{113}$ which says:

No enactment is binding on Her Majesty or affects Her Majesty's rights or prerogatives in any manner, unless the enactment expressly states that it binds Her Majesty.

This presents somewhat of a quandary since the acts involved here do not employ the usual "this act binds Her Majesty (or the Crown)" formula. In the case of the energy statutes, such a declaration would merely bind the Crown to go through the approval process and might not touch whatever ownership prerogative remains. But the Mines and Mineral Act and the Public Lands Act have excluded this prerogative if this can be done without using the precise formula just mentioned. The common law

107. Id. s. $1(\mathrm{k})$ and $(\mathrm{m})$.

108. Id. ss. $60,91-2,97$, and 122 (4).

109. Id. s. 123. There is no prerogative power to make regulations Altorney-General v. De Keyser's Royal Hotel, supra n. 100, per Lord Sumner, at 557.

110. Id. ss. 106-8.

111. Id. s. $13(1)$.

112. S.A. 1983 c. 36.

113. R.S.A. 1980, c. 1-7. 
rule was that the Crown could be bound either expressly or by necessary implication if the purpose of the statute would be wholly frustrated.114 This would seem to be a useful supplement to the words of Alberta's statute, but the Privy Council, in interpreting a similar section of Canada's Interpretation Act, has said that "it becomes apparent that it is a contradiction in terms to hold that an express statement can be found in an "irresistible implication". 115

However, this statutory obstacle to our conclusion that the Crown prerogative has been displaced is not necessarily complete. In the first place, it could be argued that the provisions of the Mines and Minerals Act referred to above amount to an explicit binding of the Crown. Secondly, in spite of the existence of such a section, it has been held that a statute rendering a "department" liable to be sued removes the Crown immunity from being sued in tort. ${ }^{116}$ Thirdly, the Interpretation Act provision was more probably aimed at other acts than those such as the Mines and Minerals Act whose whole and express intent is to regulate the exercise of the Crown prerogative.

McConnell's theory has been noted already. ${ }^{117}$ Peter Hogg believes that: ${ }^{118}$

To the extent that a government acts under prerogative authority, the references in 32(1)

10 "government" will subject it to the (Canadian) Charter (of Rights and Freedoms).

Furthermore, at least three judges of the Ontario High Court believe that the Supreme Court of Canada has left room for the common law doctrine to apply: ${ }^{119}$

An agent of the Crown is not bound by a statute unless the statute expressly so states ... or unless it is bound by necessary implication. We accept the test comtained in Province of Bombay v. City of Bombay, ... a approved in the Supreme Court of Canada in R.v. Canadian Transport Commission, .... that it is only when the benefient [sic] purpose of a statute would otherwise be wholly trusted that the inference will arise.

With respect, however, $R$. v. Canadian Transport Commission ${ }^{120}$ may not stand for this proposition. Laskin C.J.C. considered the issue at some length, but in the context of whether the Alberta government was bound by the federal Interpretation Act. He finally held, after quoting with apparent approval the relevant extract from In re Silver Brothers $L t d .^{121}$ and from Bombay ${ }^{122}$ that either the statute or the common law protected the Alberta government from being bound. He did not hold

114. Province of Bombayv. Municipality of Bombay [1947] A.C. 58 (J.C.P.C.).

115. In re Silver Brothers Ltd. [1932] A.C. 514 at 523.

116. Perepelytz v. Department of Highways for Ontario [1958] S.C.R. 161.

117. Supran. 103.

118. Peter W. Hogg, "A Comparison of the Canadian Charter of Rights and Freedoms With the Canadiand Bill of Rights" in Walter S. Tarropolsky and Gerald A. Beaudoin (eds.) The Canadian Charter of Rights and Freedoms Commentary (Toronto: Carswell Company Ltd., 1982) 1 at p. 7. Hogg cites no authority but the Perepelytz case supports his conclusion. Words in brackets have been supplied.

119. Regina v. Eldorado Nuclear Ltd. (1982) 34 O.R. (2d) 243 at 244 (Ont. High Ct. Div. Ct.), per Grange and Catzman, JJ.

120. [1978] 2 S.C.R. 61.

121. Supran. 115.

122. Supran. 114. 
that a common law gloss is to be imposed on the clear words of the statute: ${ }^{123}$

It seems to me ... that "necessary implication" is excluded if it is necessary that the Crown be mentioned or referred to in legislation before it becomes binding on the Crown.

It might also be argued that a Crown prerogative can be removed by necessary implication, while giving full force to the Interpretation Act section when Her Majesty is sought to be impleaded. This and other possibilities, however, can await another occasion, for in Alberta it has never been claimed that the relevant government decisions are based on prerogative instead of statute.

\section{CONCLUSION}

Let us recapitulate. After a general discussion of EIA, the Alberta situation was described. The author concluded that the legal mandate for EIA does not extend to a requirement of social impact assessment by the proponent, a discussion of the "do-nothing" alternative or even a justification of the project. Regulations which appear to require any such assessment are ultra vires, although the Minister may be mandated to have departmental of ficials execute these kind of studies. As for the approval process for energy related projects, the ERCB's mandate to consider socio-economic assessment is now in doubt after the Athabasca case. ${ }^{124}$ Perhaps it can advise the Lieutenant Governor in Council on broader matters, but it is possible that the latter body, exercising powers under the same statutes as the ERCB, is bound also by the narrow holding of the Supreme Court of Canada in Athabasca. It is hard to believe that the Supreme Court of Canada contemplated this result when deciding the limited point in Athabasca, and these rather bizarre possibilities would certainly support the desire to give a broader interpretation to the case.

The point in this discussion is not to criticize Alberta Environment or the ERCB for wanting social impact and other broad assessments to be done. The writer would argue for a mandate at least that broad. The key word is "mandate" and if nothing else, the preceding discussion has hopefully established the need for legislative clarification.

As well, however, decisions should be taken as to what bodies are most suitable to carry out overall environmental and socio-economic reviews of projects. If it is felt that the ERCB public hearing process is the best place for these assessments, the author would recommend that experts in these areas be appointed both to the ERCB staff and the Board itself. Further, a more liberal stance on (prospective) funding of credible public interest groups and affected interveners would be highly desirable.

123. Supran. 120.

124. Supran. 83. 